How to cite: Dobri, R.-V., Apostol, L., Sfîcă, L. (2019) Physico-Geographic Changes Produced by Air Masses Convergence Within the Central Part of Romanian Plain. 2019 "Air and Water - Components of the Environment” Conference Proceedings, Cluj-Napoca, Romania, p. 385-398, DOI: 10.24193/AWC2019_38.

\title{
PHYSICO-GEOGRAPHIC CHANGES PRODUCED BY AIR MASSES CONVERGENCE WITHIN THE CENTRAL PART OF ROMANIAN PLAIN
}

\author{
- In memoriam BORDEI-ION Nicolae - \\ Radu-Vlad DOBRI ${ }^{1}$ 囚, Liviu APOSTOL ${ }^{1}$, Lucian SFÎCA ${ }^{1}$
}

DOI: 10.24193/AWC2019_38

\begin{abstract}
The central part of the Romanian Plain, more precisely the region delimited by the rivers Prahova and Mostistea to the East and Olt to the West, is characterized from a climatic point of view by more significant precipitation amount than the areas of the West and East, being named by Bordei-Ion (1988) as an air masses convergence area of directions from $\mathrm{NE}$ and $\mathrm{E}$ with directions from $\mathrm{W}$. This area, due to the higher amount of precipitation, is evidenced by the characteristics of the physicogeographic factors such as, the types of vegetation, the characteristics of the soil cover, the use of the land or the presence of the steppes and the forests. The present work was realized using ROCADA data base (Bîrsan et al., 2014), from which all days with atmospheric precipitation values greater than $10 \mathrm{~mm}$ between 1981-2013 were extracted. This data was analyzed from a synoptic point of view using the available synoptic maps in the archive of the GFS forecasting model (Global Forecast System) available on www.wetter3.de. Thus, of the 3552 days analyzed, most days were asociated with high atmospheric instability specific for cold air advections in the form of long-wave troughs with a total of $1433(40.3 \%)$. This is followed by Mediterranean cyclones with a total number of 1008 days $(28.2 \%)$ with different trajectories according to the classification of Bordei-Ion (1983), of which cyclones with a type I track in 148 days (4.1\%), cyclones with a type II track that acted in 653 days (18.4\%) and those with trajectory IV that acted in 208 days $(5.7 \%)$. The third place in the hierarchy of pluviogenetic causes is represented by the cyclones of Atlantic origin, with a total number of 436 days (12.3\%). Cyclones with retrogressive trajectory had a 50 day (1.4\%) and cut-off-low altitude cyclones in 469 days (13.4\%). And last, warm air advections in anticyclonal regime acted in a number of 156 days $(4,4 \%)$.
\end{abstract}

Keywords: circulations, air masses convergence, physico-geographic changes, Romanian Plain.

\section{INTRODUCTION}

Through the works of 1971, 1981, 1984 and especially through the doctoral thesis sustained in 1981: "Influence of the Carpathian Curvature on Atmospheric

\footnotetext{
${ }^{1}$ „Alexandru Ioan Cuza” University of Iasi, Faculty of Geography and Geology, Iasi, Romania. dobri.vlad@yahoo.com, apostolliv@yahoo.com,.sfical@yahoo.com
} 
Circulation", a problem which was detailed and added in the book "Climatic Weather Phenomena Induced by the Carpathian Configuration in the Romanian Plain 1988", the eminent climatologist Nicolae Bordei-Ion highlighted the effect of the "wall drain" on the external frame of the Carpathians of Curvature, assimilated to the volet function, which transforms most of the Nordic circulations from southern of Moldova into north-eastern circulation in the eastern part of the Romanian Plain. The effect of the volet, discovered by Coanda H. in 1910, was applied in various fields of practice in Romania, among others, by TeodorescuTुintea in the years 1960, 1963 and 1963 b (Bordei-Ion, 1988), but the merit of its application in climatology, in the case of "the great curvature" belongs to BordeiIon N. Another major problem highlighted in the book was the detection of some thermal contrasts and lines of discontinuity in the central area of the Romanian Plain, and especially the interference of torsion currents from the North-East to the western ones, a phenomenon that produces increased amounts of precipitation, comparative with the areas in the east, west and south of the interference area and other hydro-climatic phenomena, impacting on some physico-geographic components of the environment.

Through his valuable ideas, the book of Bordei-Ion $\mathrm{N}$ resisted in time, being topical, based on subsequent research of many climatologists, who analyzed, supported and developed these original results, researches on which he makes a retrospective, until 2007, Aurora Stan-Sion in the second edition of the book "Climate phenomena induced by the Carpathians in the Romanian Plain (1988). Only between 1999-2007, the NMA researchers drew up 16 papers on topics related to this work. Throughout the country, for the entire period after 1988, the number of papers inspired by this book is much higher.

In this way, there are also our considerations regarding the area of convergence of the air masses circulation in the center of the Romanian Plain. The following issues have been addressed in this paper:

- torsion of the western circulation by the north-eastern curvature (named as the "great curvature", by Bordei-Ion N., being of the Carpathians of the Curvature, where the Carpathian direction changes with $90^{\circ}$ in a restricted space), through which the western circulation of the north of Carpathian is converted into north-western and then northern circulation;

- some considerations about the convergence area;

- the delimitation of the convergence area based on the characteristics of the atmospheric precipitation, other hydro-climate elements and phenomena and the environmental impact.

In the same context, we should mention that in the subchapter "Climatic and Topoclimatic Regions" in Geography of Romania, vol. I (1983), Octavia Bogdan highlights a climate province sector, called "transition", transition from oceanic and Mediterranean influences to aridity in the central-southern part between Jiu and Arges. Because this transition sector also includes the area of interference of the Romanian Plains, there were presented also some considerations on this issue. 


\section{DATA AND METHODS}

The present work was realized by analyzing ROCADA data (Bîrsan et al., 2014), and producing the cartographic materials which describe multiannual average number of hours of sunshine, multiannual average number of days with nebulosity greater than $5 / 10$ and multiannual average precipitation over the measurement range 1961-2013. It was also realized the cartographic materials which describe the average multiannual amount of precipitation in all the seasons and in the warm semester. These were performed using the linear regression between the amount of precipitation and the relief elevation. Then, the residues were calculated by decreasing the regression from ordinary kriging and finally the cartographic materials presented in these articles were made by adding residual kriging with linear regression. These were performed using the specialized GIS software such as TNT Maps 6.9 or ArcGis 10.3. Not least, different materials have been used to highlight the phenomena that occur in the studied area

\section{RESULTS AND DISCUSSIONS}

The relatively extensive area occupied by the Romanian territory, the predominantly western atmospheric circulation of the temperate zone, the position of the main cyclone and anticyclone centers, the proximity to the Atlantic Ocean and its seas, as well as the Mediterranean and its seas, the south-west, west and northwest mountains of our country and the configuration of the Carpathian arch induce major changes in the direction of the wind on the territory of Romania, while the west still remains the main direction. Taking into consideration the complementary directions from Northwest and Southwest, the western component is the prevalent. In a straight line, the smallest distance from the center of the convergence area to the mentioned seas is $450 \mathrm{~km}$ to the Aegean Sea, $600 \mathrm{~km}$ to the Adriatic, 1300 to the Baltic Sea, $1700 \mathrm{~km}$ to the North Sea, $2000 \mathrm{~km}$ to the English Sea and $2150 \mathrm{~km}$ to the Bay of Biscay.

In the approximately $1500 \mathrm{~km}$ of the Carpathian mountain chain, the longest mountain chain in Europe stretching between Vienna and the Timoc Valley, there are three major inflows, the first being the northeastern curve, almost a semicircle, with an extension of $135^{\circ}$, from Vienna to the Trotus Valley, with a length of approximately $950 \mathrm{~km}$; the second, the Carpathians of the Curvature, with a length of approximately $150 \mathrm{~km}$, with a 90-degree extension, on the narrowest space, called the "Great Curve" (Bordei-Ion, 1988); a straight sector, the east-west sector (Bucegi, Fagaras-Parang, about $150 \mathrm{~km}$ ); and the third one, the southwest curvature, the most complex, between the Jiu valley and the Timoc valley, with a length of approximately $250 \mathrm{~km}$, with an extension of $180^{\circ}$.

Western circulation in the northern temperate area has been clearly emphasized since the beginning of the 19th century. (Brigham et al., 1916), and was fundamented from scientific point of view, half a century later by Maury (1955) 
and Ferell (1856). In periods of low cyclonic activity, ground level circulation is trained in the sense of the parallel, from west to east, by the general circulation existing in the free atmosphere (Donciu, 1958).

The predominant circulation in Central Europe, at a height of $3000 \mathrm{~m}$, is western (Wagner, cited by Stoenescu, 1951). This stream also includes the entire Balkan Peninsula, and also our country (Stoenescu, 1951). The average troposphere currents, at the latitude of the northern half of our country, splits in the north of the Panonic Plain, a flow continuing west-east circulation, the other taking the direction from west-north-west to east-south-east.

The analysis of the altitude wind, for the period 1955-1964, performed for the $10 \mathrm{~m}, 100 \mathrm{~m}, 500 \mathrm{~m}, 2000 \mathrm{~m}$ and $4000 \mathrm{~m}$ aerodynamic levels, shows the prevalence of western components in the western half of Moldova. At Suceava, western circulation is more frequent than the northwester circulation, and at Bacau the northern circulation is at higher altitudes than $500 \mathrm{~m}$ in winter and between 1000-1500 $\mathrm{m}$ in summer (Cristodor et al., 1968).

As the circulations in the north direction, in the south of Moldova, turns to the northeast for the East of the Romanian Plain, through the torsion process, which results from the air circulation (from the north) to the convex part of the Curvature Subcarpathians (Bordei-Ion, 1988), a similar phenomenon with larger space expansions, is produced by the torsion of the western circulation, which follow the northern part of the Carpathian chain and is molded on the northeastern part and then on the eastern part of the Carpathian chain, becoming northwestern and then, northern circulations (Fig 1).

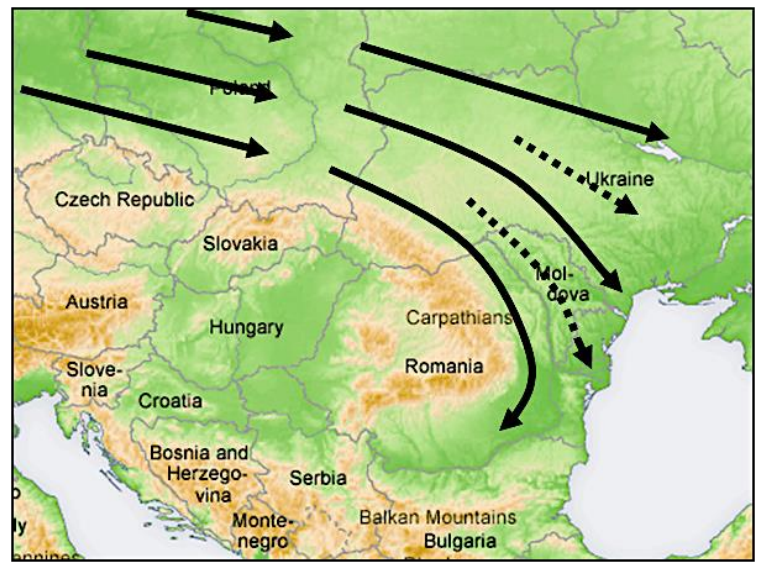

Fig. 1. Spatial distribution of the wind streamlines at the east of the Carpathians in the western circulation in the German-Polish Plain (Apostol and Sfícă, 2011).

The phenomenon occurs in the subcarpathian area with the same effects as in the southeast of the Carpathians of the Curvature: cavitation phenomena generating depression zones, divergence of the current lines and catabatic currents from the mountain area. The dominance of the northern direction in southern Moldova is 
also the effect of composing the northern, northeastern and eastern circulation, shrouded and redirected southward from the obstacle constituted by the Oriental Carpathians. The currents on the respective directions are channeled through the "funnel" formed by the Eastern Carpathians and the thermal barrier blocked by the Black Sea (Drăghici, 1988). When the cold air masses from northern Europe or from the Russian Plain advancing to Romania, having small thicknesses, the Romanian Carpathians have the role of a barrage, only Moldova, Dobrogea, Muntenia and Olteni are maining exposed, over which the cold air is installed in the Balcano-Carpathian area (Bordei-Ion, 1988). Through these processes, the dominated direction in northern Moldova becomes northwest, and in its southern part, the north (Apostol, 2000, 2004).

This major direction in the south of Moldova is converted in a northeast direction because of the torsion along the outer flank of the "Great Curve" (Bordei-Ion, 1988), (Fig. 2). Behind the Brăila and Ialomiţa ponds, the north remains dominating, which continues the Nordic currents from the eastern part of southern Moldova, too far from the Volet Curvature, in order to be torsioned in the North-East directions.

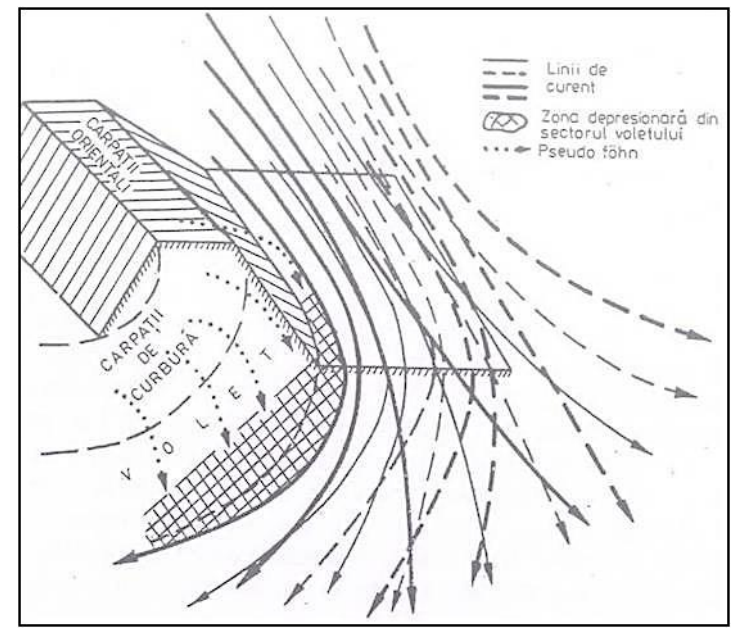

Fig. 2. The schematic diagram of the spatial distribution of the current lines in the extra-Carpathian sector of the Curve in Northern Circulations (Bordei-Ion, 1988).

Though deviated twice, the Western circulation of the Northern Carpathians proves to be strong after it has traveled about $500 \mathrm{~km}$ along the eastern and southern Carpathians, to pass then as a north-eastern component, inside the Romanian Plain through its center, to Arges, where it is stopped by the main western circulation, but it can advance on the northern and southern flank to the Vedea River (Fig. 3). This is because the western circulation of the Romanian Plain is the result of the western currents that penetrate here over the low Carpathian region, along the Danube river. Even before this sector, the western circulation is not strong, being the result of the cumulation of the north-western preponderance circulation of the Pannonian Plain with the southwest of the Sava valley, which 
diverted to the north and south of the Alps, blocked by them in the lower and even medium troposphere.

The processing of Fig. 3, although based on an average wind direction from 4 weather times observations, does not differ much from the one determined by Bordei-Ion N. in 1988. The area of interference was delimited by Bordei-Ion N.

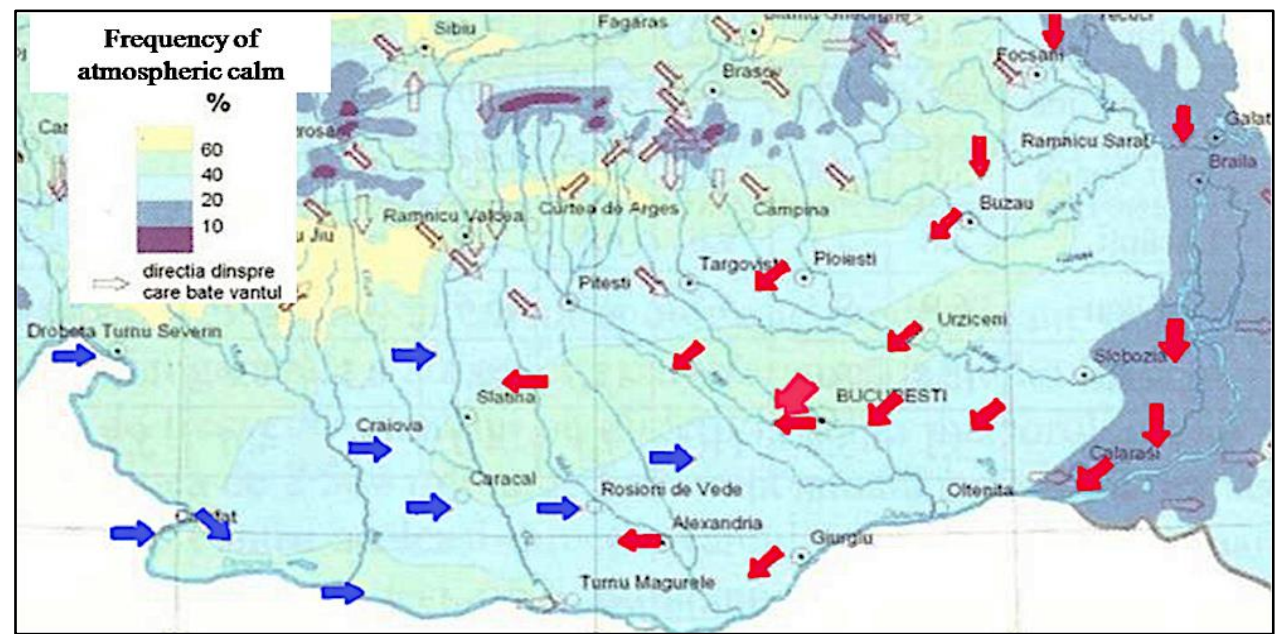

Fig. 3. The wind direction and the frequency of atmospheric calm in the Romanian Plain (Processing by Climate of Romania, 2008)

between the Carpathians to the north, the rivers Prahova and Mostistea to the east, the Danube River to the south and the Olt River to the west. The author argues the different pluviometric characteristics in this area, by processing from the Atlas RS Romania (1972-1979), highlighting between Olt and Dâmboviţa an area with the highest maximum rainfall in 24 hours in Romania, along with Subcarpathians of Oltenia, Subcarpathians of Curvature, southern Moldova and the seashore, and by presenting, after said work, the average rainfall in the warm semester, in the area being over $300 \mathrm{~mm}$; the real annual average evaporation between $500 \mathrm{~mm}$ and 550 $\mathrm{mm}$; annual humidity deficit between $150 \mathrm{~mm}$ and $200 \mathrm{~mm}$.

In addition, the impact on humidity and vegetation is noticeably highlighted, according to N. Cernescu and P. Coteţ (1976), the area of interference has a "Martonne" aridity index between 24-30 and in the Danube meadow between 2024 , the area of the vegetation being silvosteppe with oak forests, towards the south, towards the Danube valley, steppe, and at the northern limit, the area of the oak forests (Fig. 4). Compared with the parameters presented, the evolution in time did not show any major changes. For the area of interference, in Geography of Romania vol I (1983), the aridity index of "Martonne" has values in the interference area between 25-30, and in the Vedea and Neajlov river basins, under 25. Croitoru et al (2013), evaluates this area as wet, whit this index between 28-35, and the Vedea and Neajlov river basins, less wet, with the "Martonne" index between 24-28. 


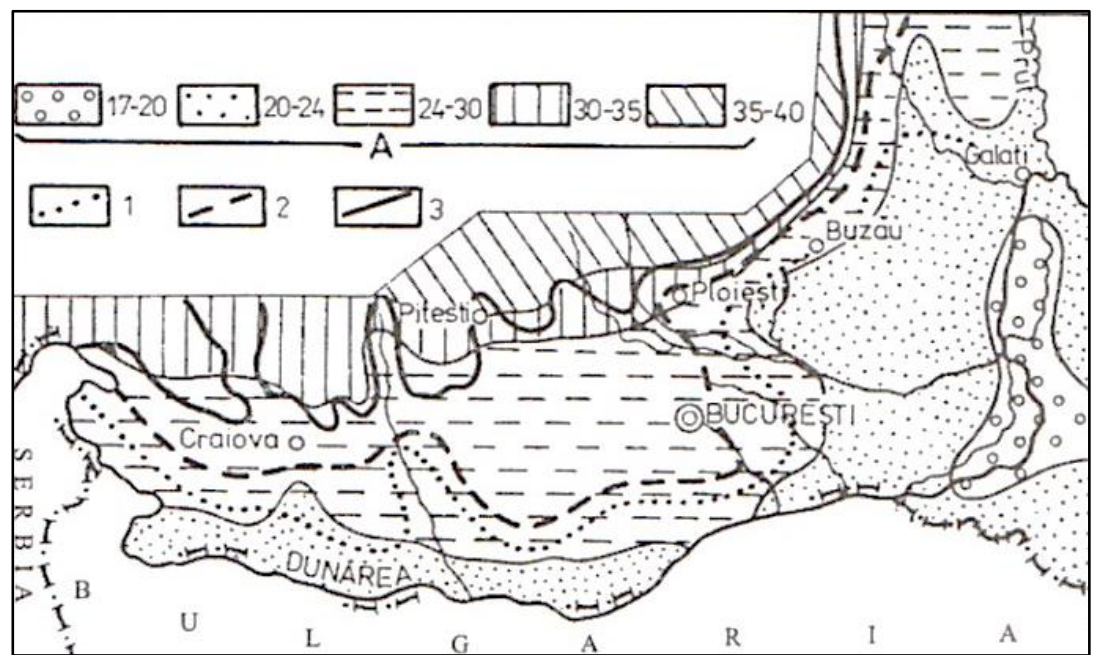

Fig. 4. Correlation between the regions of humidity (with the respective indices listed in the box, after $N$. Cernescu) and the vegetation and relief areas (after P. Cotet). 1-steppe limit; 2 - the limit of oak forests; 3 - the limit of the beech forests; A-Humidity indices (Cernescu).(Bordei-Ion N., 1987).

The constant of the index values over time is due to the fact that, in the conditions of the temperature increase, the precipitations had a slight increase.

Regarding the amounts of precipitation in the area of interference, for the period 1961-2013, by ROCADA data, meteo-climatic elements have been determined which individualize the specificity of this area.

Thus, the multiannual average of the sunshine duration for the 53 years analyzed was between 2150 and 2200 hours, at the northern boundary to 2050 hours, compared to 2200-2300 in the western and east plain (Fig. 5A). The average annual number of days with average nebulosity over 5 tenths was between 202 days and 217 days, compared to 192-202 days in the western and eastern plain areas (Fig. 5B).

The main parameter for highlighting and delimiting the interference area in the Romanian Plain is the average multiannual rainfall. It has values between $560 \mathrm{~mm}$ in the southern area and $725 \mathrm{~mm}$ at the northern limit. Practically, the highlighted area has values between $560 \mathrm{~mm}$ and $660 \mathrm{~mm}$, isohyetes that can constitute the controllable limits of the area in the plain area. The neighboring areas of the plain from the west have values ranging from 550 to $500 \mathrm{~mm}$ and in the east $420 \mathrm{~mm}$ (Fig. 5C).

In the seasons, the differences are greater in the cold season and in the transition seasons, with intensified western circulations. Thus, in winter, the limit of the area is $115 \mathrm{~mm}$, in the south and north are islands where the values increase, but not more than $135 \mathrm{~mm}$ (Fig. 6A). In western plain areas, the values are down to 105 $\mathrm{mm}$ and in the east, even up to $75 \mathrm{~mm}$, highlighting the high role in this season of direct western circulation from the Danube. In the spring, the average rainfall in the area is homogeneous and has values from $145 \mathrm{~mm}$ to $155 \mathrm{~mm}$, the western plain has $135 \mathrm{~mm}$ to $145 \mathrm{~mm}$ and the east has values between $105 \mathrm{~mm}$ and $145 \mathrm{~mm}$ (Fig. $6 \mathrm{~B})$. In the summer, circulation interference is less obvious, and the area is less 
highlighted. A wide area, with values above $170 \mathrm{~mm}$, covers almost the whole Romanian Plain, except for Southern Oltenia and Bărăgan.

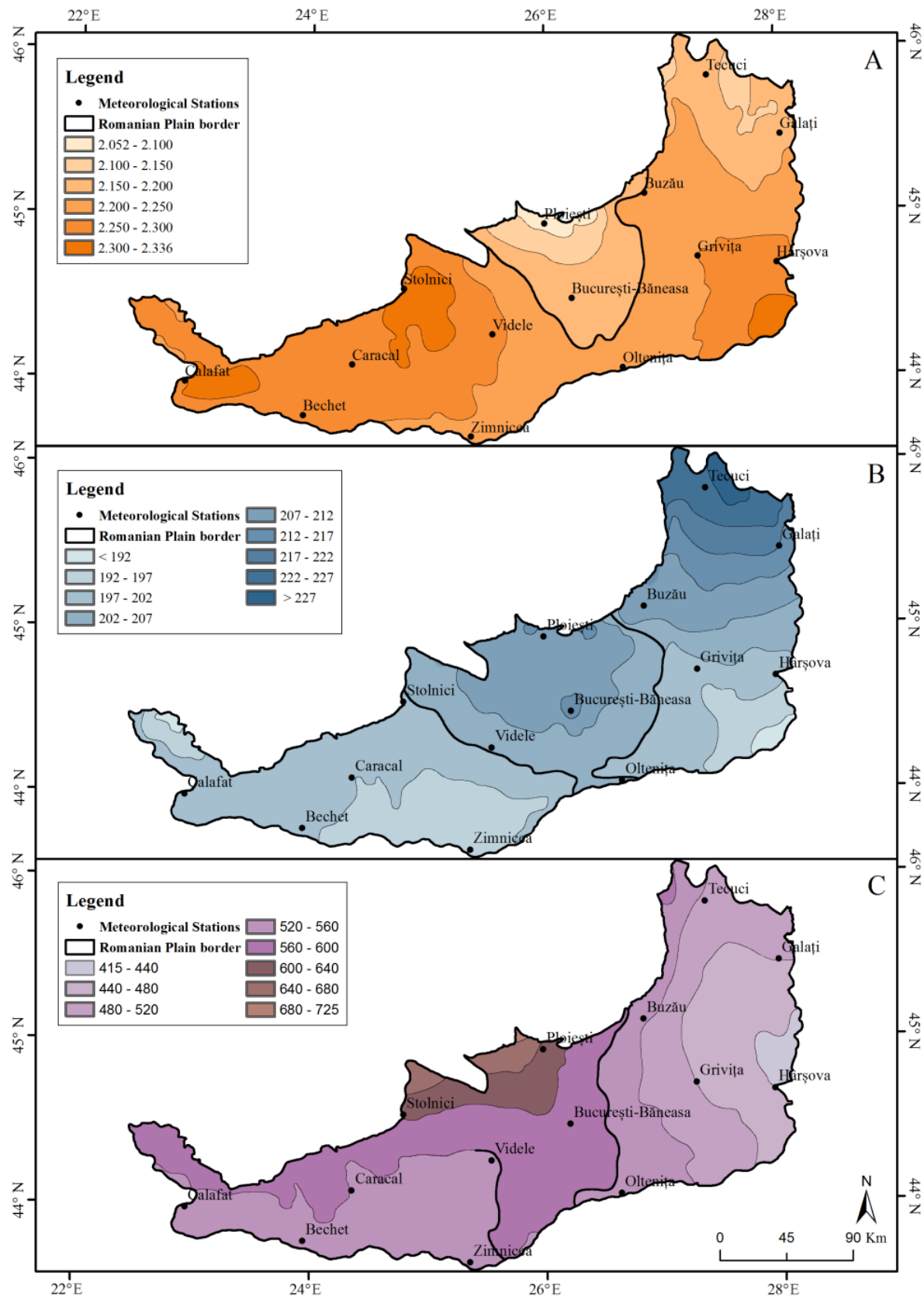

Fig. 5. Multiannual average number of hours of sunshine (Figure A), multiannual average number of days with nebulosity greater than 5/10 (Figure B) and multiannual average rainfall (Figure C) over the measurement range 1961-2013 (for all figures). 
The interference area is withdrawn northwards, with the shape of a cloud-based triangle, with values of precipitation between $190 \mathrm{~mm}$ and $230 \mathrm{~mm}$, in the northern extremity, in the high plains of Pitesti and Ploiesti, even more than $250 \mathrm{~mm}$ (Fig. 6 C).

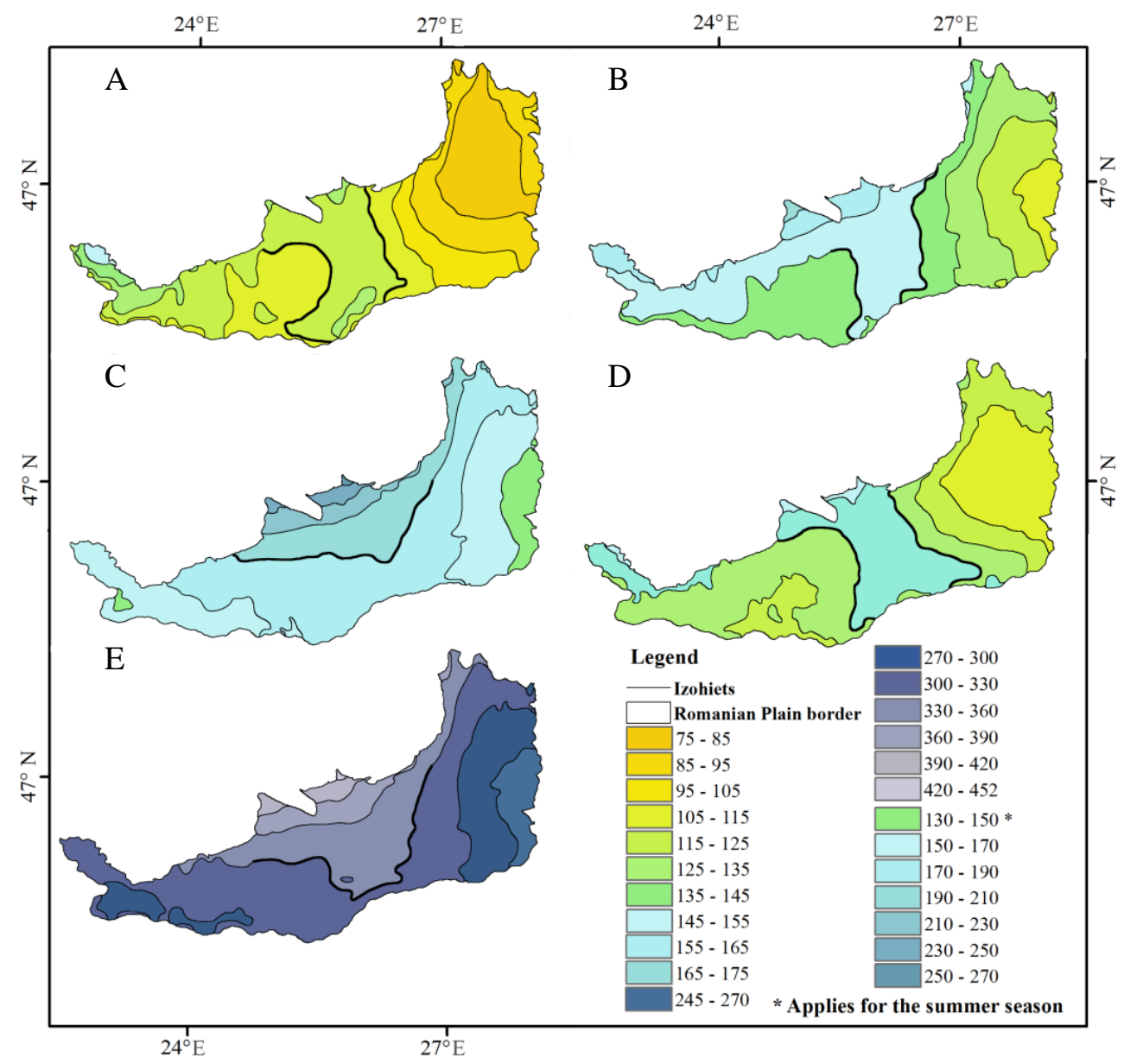

Fig. 6. The average multiannual amount of precipitation in winter $(A)$, spring $(B)$, summer $(C)$, autumn $(D)$ and warm semester $(E)$ for the period 1961-2013

In the autumn (Fig. 6D), the average rainfall area extends, especially in the southern part, with values higher than $125 \mathrm{~mm}$ in the Danube valley between Oltenita and Turnu-Magurele, with values higher than $135 \mathrm{~mm}$ in the central part. The quantities in the warm semester, which is the vegetation season, are values higher than $330 \mathrm{~mm}$, and in the northern extremity they reach more than $420 \mathrm{~mm}$ (Fig. 6E).

The amount of rainfall in the area of interference is mostly caused by cyclonic activity. Thus, of the 3552 days analyzed, most days were determined by high atmospheric instability associated with cold air advections in the form of longwave troughs with a total of 1433 (40.3\%), followed by Mediterranean cyclones with a total number of 1008 days (28.2\%) with different tracks according to the 
classification of Bordei-Ion (1983), of which cyclones with a type I track in 148 days $(4.1 \%)$, cyclones with a type II track that acted in 653 days $(18.4 \%)$ and those with trajectory IV that acted in 208 days $(5.7 \%)$. The third place in the hierarchy of pluviogenetic causes is cyclones of Atlantic origin, with a total number of 436 days $(12.3 \%)$. Cyclones with retrograde trajectory had a 50 day $(1.4 \%)$ and cut-off-low altitude cyclones in 469 days (13.4\%). And last, warm air advections in anticyclonal regime acted in a number of 156 days $(4,4 \%)$.

In the central part of the Romanian plain, the largest amounts of precipitation are produced by Mediterranean cyclones with a type IV track and by high atmospheric instability associated with cold air advections in the form of longwave troughs and also with cut-off low cyclones identified in the middle and upper troposphere in South-East Europe (Dobri et al., 2017).

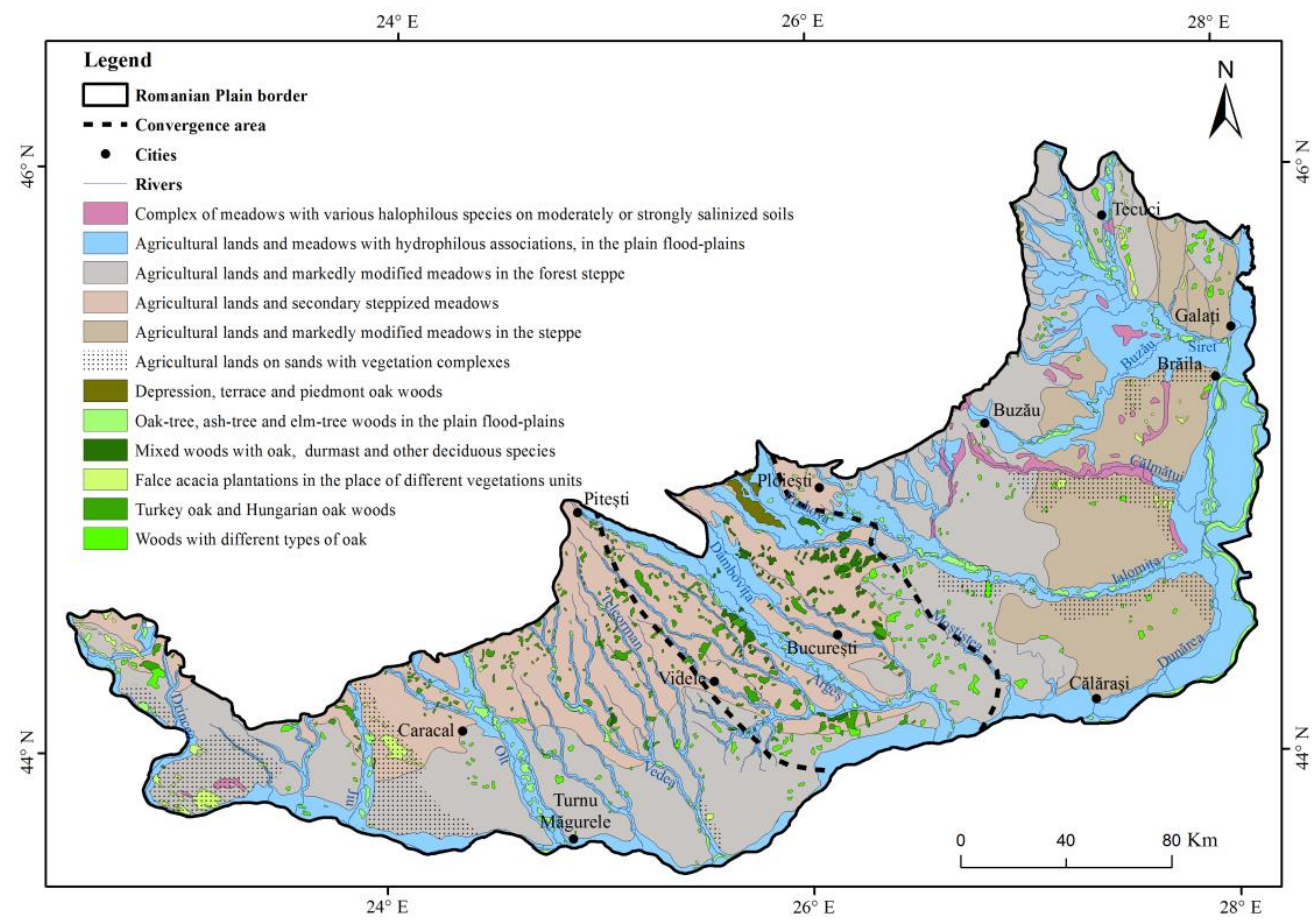

Fig. 7. Types of vegetation and their territorial extension in the Romanian Plain (Processed after the Atlas R.S. Romania, 1972)

The physico-geographic components, especially vegetation and soils, also mark the pluviometric features of the area. Natural vegetation, but especially soils, signals the old extension of this area. For this reason, it is assumed that certain characteristics of the general circulation of the atmosphere have changed. The area of interference vegetation consists of: agricultural lands and markedly modified meadows in the forest steppe in the majority of territory; agricultural lands and secondary steppized meadows in the Mostiștea Plain; agricultural lands and meadows with hydrophilous associations in the flood plains on the several rivers valleys (Fig. 7). Woods, in forest steppe are 
represents by woods with different types of oak in Mostiștea Plain and in the southern part of area, turkey oak and Hungarian oak woods; mixed woods with oak, durmast and other deciduous species in Neajlov river basin.

Soil types in the SRTS $(2000,2012+)$ are the preluvosols in the contact with the drier areas in west, south and eastern parts, luvosols in the central part between the Vedea and Dâmboviţa rivers and narrow areas with vertisols on the interfluvial plains at west of the Neajlov river (Fig. 8). The soil cover presents the previous climatic situation at a level of one or two thousand years.

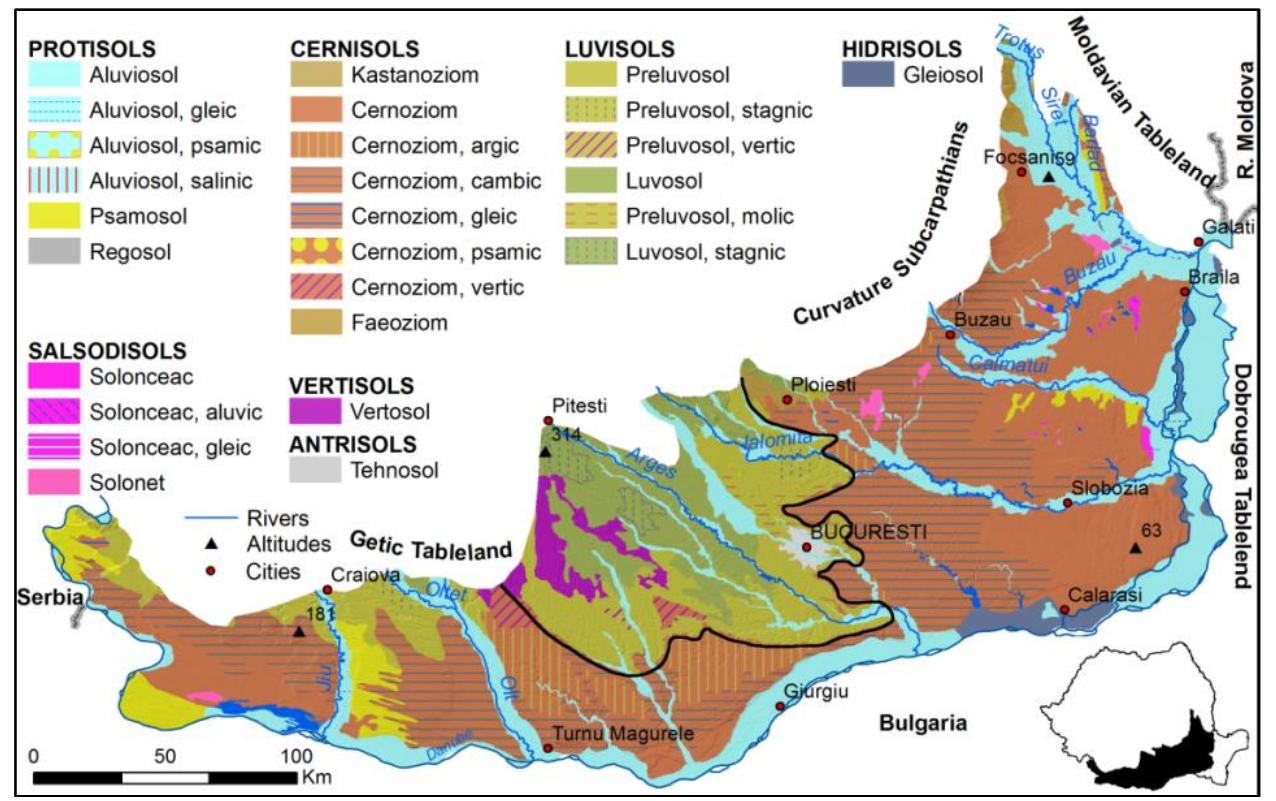

Fig. 8. Soil types and their territorial extension in the Romanian Plain Processed. Author: (C) Cristian Secu

Obviously, over the last 80 years, due to climate change, especially global warming, mutations in the expansion of various climatic districts in the area of interference have been recorded as well as in the whole country, especially as Romania is on the border between the sectors D and C (Köppen, cited by Cernescu, 1934). Due to the aspect that could be related to climat change, the climatic classification of these pedological areas became Cfax, a phenomenon produced in that period on a quarter of the country's surface, as the climate of Romania became, according to the Köppen classification, due to the average temperature rise in January from the predominantly boreal with cold winter (D) in temperate rainy weather (C).

The area of circulation interference in the central part of the Romanian Plain is framed by Octavia Bogdan in the Map of Climatic Regions and Topoclimates in Geography of Romania, vol. I (1983) in the forest vegetation district, except for the Burnaz and Mostistei plains framed in the vegetation district and in the climatic map of Atlas RS Romania (1972-1979), in the climatic forest district, except for the Burnaz and Mostistei plains, which are part of the climatic zone of the forest steppe (Fig. 9). 
In our opinion, another transition area in the temperate climate, which occupies almost entirely the territory of our country, except for the steppe area, not between different types of climates but between climatic province sectors that do not have major differences between them, is not so representative.

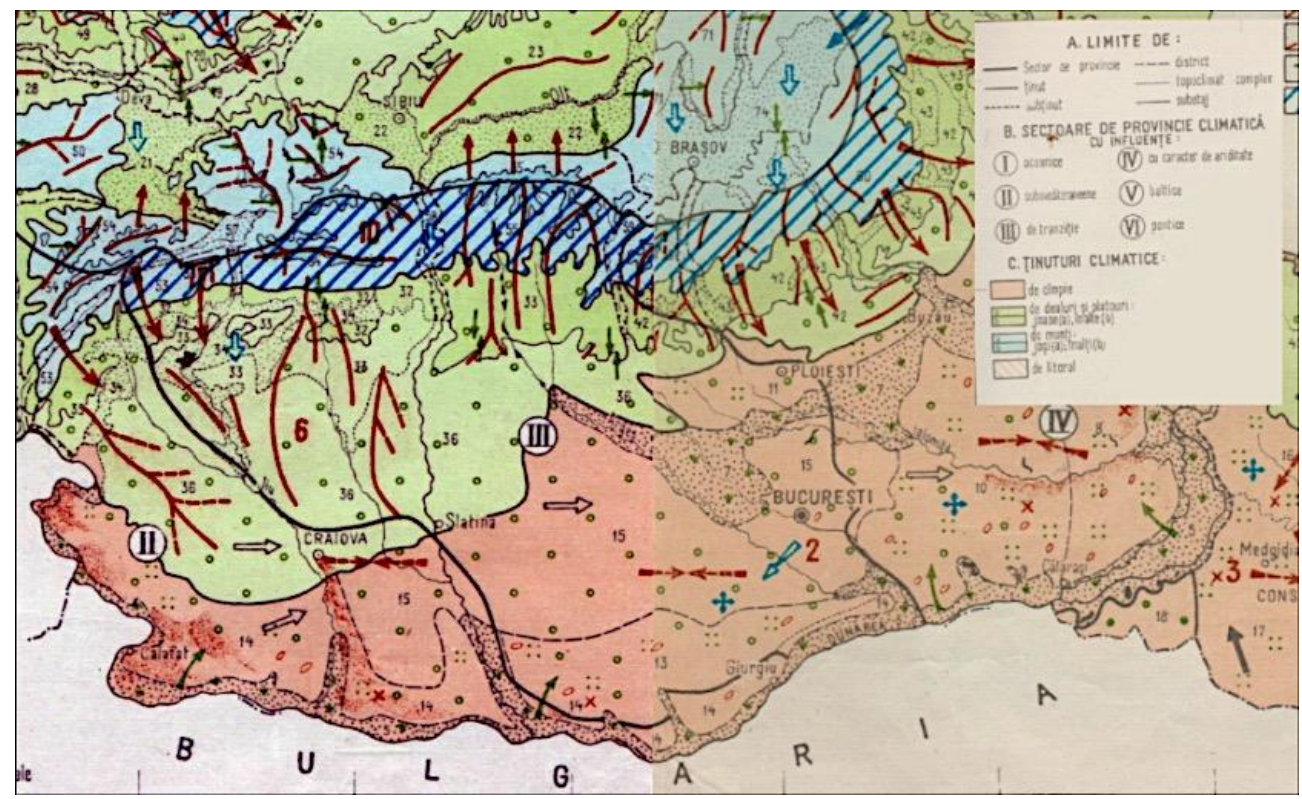

Fig. 9. Section of the Climate Regions in Romania, by Octavia Bogdan (Geography of Romania, vol. I, 1983)

In addition, the sector is composed of heterogeneous areas: the wet area of interference in the center of the Romanian Plain; the plain area between Vedea and Olt rivers, where the transition to the so-called mediterranean influence is almost imperceptible; northwest highland, Getic Plateau, Getic Subcarpathians and southern slopes of the Valcan, Parîng, Retezat and Făgăraş Mountains, where the altitude produces lower temperatures and higher rainfall. Another area where the lower altitude favors higher temperatures is in the depressions of the Subcarpathians of Oltenia, and the mountain slopes between Jiu and Motru where the precipitations of the Mediterranean cyclones are better received. The southern area of the Southern Carpathians is the most complex from a climatic point of view, with its central part being reported as a high precipitation area, compared to the west and the east (Bordei-Ion, 1988).

This wetter area, generated by the convergence of the two dominant air masses circulation, northeastern and eastern circulation with the western circulation, is more homogeneous and can be highlighted by the average rainfall values as well as the density of the rivers, the low depth of the groundwater, the presence of silviculture and forest and by the characteristics of the soil cover.

According to the dominant frequency of the wind direction, the north-east wind penetrates until Slatina in the north, to Bucharest in the center and Alexandria to the south, and the dominant direction of the west wind, between the two areas, from the 
low area of Carpathians, from the Danube defile, to Neajlov (Apostol, Dobri, 2018). The larger area (including partly and the one mentioned), between Mostiştea and the Prahova valley to the east and the Olt valley to the west, including the northern Oltenia to Motru, is highlighted and named by Bogdan (1983) "climate province with transitional influences", but in reality represents just a result of the way that the atmospheric circulation is influenced and modified by the complex orography of Carpathian mountain. It should be mentioned additionally that in our opinion this region represents from a climatological point of view a discontinuity within the climate of Romanian plain, and not a transition between climatic provinces.

\section{CONCLUSIONS}

Taking into consideration all the arguments presented, the boundaries of the interference area of the air masses circulation in the center of the Romanian Plain are best evidenced by the annual rainfall quantity, being the limits of the other parameters of rainfall as well as vegetation and soils and, after three decades, in which climate change has taken place, not far from those marked by Bordei-Ion N (1988).

The southern boundary of the area is the Danube, and the northern one is the boundary of the Romanian Plain between Vedea and Prahova. The difference is in the change to the east of the limit of the interference area, from Olt, to Vedea. Between these limits, the area includes the Pitesti Plain, the Targovişte-Ploiesti Plain, the Gavanu-Burdea Plain, the Titu-Gherghita Plain, the Vlasia Plain, the Mostistei Plain and the Burnaz Plain. The frequency of Mediterranean cyclones in the studied area is double that of the Atlantic cyclones. Regarding the climatic region, we believe that the attachment of the atmospheric circulation area of the Romanian Plain to the transitional climatic province sector (Bogdan, 1983, in Geography of Romania vol. I) does not have enough arguments, being in the sector with aridity influences.

\section{REFERENCES}

1. Apostol L. (2000), Atmospheric precipitation in the Subcarpathians of Moldova, Publish. of Univ. of Suceava (in Romanian).

2. Apostol L. (2004), Climate of the Subcarpathians of Moldova, Publish. of Univ. of Suceava (in Romanian).

3. Apostol L., Sfícă L. (2011), Influence of the Siret River Corridor on wind conditions, Prace i Studia Geograficzne, T. 47, Wydział Geografii i Studiów Regionalnych, Uniwersytet Warszawski, ISSN 0208-4589, p. 483-492.

4. Apostol L., Dobri R.-V. (2018), Considerations on some climate transition areas in the southern Meridional Carpathians, al XXXVIII-lea International Scientific Seminar „D. Cantemir "Al. I. Cuza "University of Iasi.

5. Birsan M.V., Dumitrescu A. (2014): ROCADA: Romanian daily gridded climatic dataset (1961-2013) V1.0. National Meteorological Administration, Bucharest, Romania, doi:10.1594/PANGAEA.833627 
6. Brigham A.P., McFarlane Ch. T. (1916), Essentials of Geography, New York, NY: American Book Company.

7. Bordei-Ion N. (1971), Problems of air circulation in the Carpathians area of the Curvature, La V-ème Conférence de Météorologie des Carpates, Sofia (in French).

8. Bordei-Ion N. (1988), Climatic phenomena induced by the Carpathian configuration in the Romanian Plain (in Romanian).

9. Bordei-Ion N. (2008), Climatic phenomena induced by the Carpathian configuration in the Romanian Plain, Ed. a II- $a$, reviewed by Ecaterina Bordei-Ion, Publish. of Academy, Bucharest (in Romanian).

10. Bordei-Ion N., Bordei-Ion Ecaterina (1981), Some weather-climate syntheses concerning the Romanian Plain, imposed by the configuration of the Romanian Carpathians, Miedzynarodowa Konferencja Meteorologii Karpackiej, Krakow.

11. Bordei-Ion N., Bordei-Ion Ecaterina (1984), The curvature Carpathian foehn and its implications in geographycall and scape of the Baragan Plain, XVIIIth International Conference for Alpine Meteorology, Opatija, Beograde.

12. Cernescu N.C. (1934), Facteurs de climat et zones du sol en Roumanie, Technical and Economic Studies, C Series, Soil Science, no. 2, Romanian Geological Institute, Bucharest (in French).

13. Ciulache S. (1981), Climate map of the world, sc. 1:22.000.000, Didactic and Pedagogical Publish., Bucharest, (in Romanian).

14. Cristodor E., Darie Z., Ranga M., Masichievici G., Ionescu, F., Mesaroș E., Curelea N. (1968), The wind regime over the territory R.S.R., Collection of papers, Meteorological Institute, Bucharest.

15. Croitoru A.E., Piticar A., Imbroane A.M., Burada D.C. (2013), Spatiotemporal distribution of aridity indices based on temperature and precipitation in extraCarpathian regions of Romania, Theor. Appl, Climatol, 112:597-607.

16. Dobri, R. V., Sfî̀că, L., Ichim, P., \& Harpa, G. V. (2017). The Distribution of the Monthly 24-Hour Maximum Amount of Precipitation in Romania According to their Synoptic Causes. Geographia Technica, 12(2), 62-72.

17. Donciu C. (1958), Variation of air circulation in the south of $R$. P. R., Meteorology, Hydrology and Water Management, no. 2-3, Bucharest (in Romanian).

18. Ferell W. (1856), An essay on the winds and the currents of the ocean, Nashville, USA.

19. Manea A., Nikolova N., Boroneanț C., Orzan A. (2010), Changes in the annual cycle and seasonal characteristics of precipitation in the Danube river lower basin, Romanian Journ. of Meteorology, vol. 10, nr. 2, ANM, București

20. Maury M.F. (1855), Physical geography of the sea, Harper \& Brothers Publish., New-York.

21. Stoenescu Șt. (1951), Climate of Bucegi, Technical Publish., Bucharest (in Romanian).

22. *** (1972-1979), Atlas - R. S. R., Academy Publish., Bucharest (in Romanian).

23. *** (1983), Geography of Romania, vol. I, Academy Publish., Bucharest (in Romanian).

24. *** (2000), Romanian Taxonomy System of Soil - SRTS 2000, INCDPAPM - ICPA, Bucharest (in Romanian).

25. *** (2008), Climate of Romania, National Meteorological Administration, Romanian Academy Publish., Bucharest (in Romanian).

26. *** Meteorology Glossary, American Meteorological Society, http://glossary.ametsoc.org/wiki/Westerlies.Accesed on 12.01.2019.

27. *** https://www.meteoblue.com/en/weather/forecast/modelclimate/.Accesed on 12.01.2019

28. $* * *$ https://www.wetter3.de.Accesed on 12.01.2019 